\title{
Prevalence of Dyslipidemia and Associated Factors in Obese Children and Adolescents
}

\author{
Selin Elmaoğulları1, Derya Tepe1, Seyit Ahmet Uçaktürk1, Fatma Karaca Kara2, Fatma Demirel3 \\ ${ }^{1}$ Ankara Children's Hematology and Oncology Training and Research Hospital, Clinic of Pediatric Endocrinology, Ankara, Turkey \\ 2Ankara Children's Hematology and Oncology Training and Research Hospital, Biochemistry Laboratory, Ankara, Turkey \\ 3 Yıldırım Beyazıt University Faculty of Medicine, Ankara Children's Hematology and Oncology Training and Research Hospital, \\ Clinic of Pediatric Endocrinology, Ankara, Turkey
}

\begin{abstract}
Objective: Childhood-onset obesity is associated with increased mortality and morbidity related to cardiovascular diseases (CVD) during adulthood. Dyslipidemia has a fundamental role in the pathogenesis of CVD. This study aimed to evaluate the prevalence of dyslipidemia and related factors among obese children and adolescents.

Methods: Obese patients aged between 2 and 18 years were included in the study. Serum concentrations of total cholesterol (TC), triglyceride (TG), low-density lipoprotein (LDL-C), high-density lipoprotein (HDL-C), fasting glucose levels, insulin, thyroid-stimulating hormone (TSH), free thyroxine $\left(\mathrm{fT}_{4}\right)$, alanine aminotransferase (ALT), aspartate aminotransferase (AST), and liver ultrasound findings were evaluated retrospectively.

Results: Among 823 obese patients, $353(42.9 \%)$ met the dyslipidemia criteria: $21.7 \%$ had hypertriglyceridemia, $19.7 \%$ had low levels of HDL-C, $18.6 \%$ had hypercholesterolemia, and $13.7 \%$ had high levels of LDL-C. Older age and/or high body mass index (BMI) were related to increased prevalence of dyslipidemia. Hepatosteatosis was more common among dyslipidemic patients. The frequency of insulin resistance (IR) and of higher levels of ALT and TSH were also detected in dyslipidemic patients. Patients with both dyslipidemia and grade 2-3 hepatosteatosis had higher levels of ALT, AST and TSH and lower levels of $\mathrm{fT}_{4}$.

Conclusion: Prevalence of dyslipidemia is high in obese children, and hypertriglyceridemia is in the foreground. Higher levels of $I R$ and more apparent abnormal liver function test results are observed in the context of dyslipidemia and hepatosteatosis coexistence. Metabolic and hormonal alterations related with thyroid functions may also be associated with dyslipidemia and hepatosteatosis in obese patients.

Key words: Dyslipidemia, obesity, children, adolescents
\end{abstract}

Conflict of interest: None declared

Received: 08.01.2015

Accepted: 05.07 .2015

\section{Introduction}

The worldwide prevalence of obesity in children has increased in the past 3 decades (1). It is estimated that there are 43 million overweight and obese children under 5 years of age worldwide (2). The prevalence of overweight and obesity in Turkish children is lower than that reported for North and South American countries and similar to North European countries (3).

Obesity is considered as an important public health problem by the World Health Organization (WHO) (4). It constitutes a major risk factor for cardiovascular disease (CVD), which is known to be the main cause of death and morbidity in adults. CVD-related symptoms generally appear in the fourth decade of life, but development of atherosclerosis is known to begin at earlier ages and to be related to dyslipidemia (5). In autopsy studies, it has been shown that fatty lines which are early signs of atherosclerosis can be determined even at the age of 2 and it has also been found that plaque thickness is proportional to age, body mass index (BMI), serum total cholesterol (TC), triglyceride (TG), low-density lipoprotein (LDL-C) and inversely proportional to high-density lipoprotein (HDL-C) (6). In addition to obesity and dyslipidemia, insulin resistance (IR) and high blood pressure, which are components of the metabolic syndrome, are also risk factors for CVD development (7). In order to decrease CVD-related death and morbidity in adulthood, obesity and dyslipidemia should be prevented in children and adolescents. In this retrospective study conducted on a large population of Turkish children, we aimed to evaluate the frequency of dyslipidemia and related factors in obese children and adolescents. 


\section{Methods}

The records of cases aged between 2 and 18 years and diagnosed with obesity in the time period between 2011 and 2013 at Ankara Children's Hematology-Oncology Training and Research Hospital Pediatric Endocrinology clinic were evaluated retrospectively. Data relating to age, anthropometric measurements, pubertal state, BMI, lipid profile, insulin resistance (IR), thyroid function tests, liver function tests, and presence of hepatosteatosis at admission were recorded from patient files, and the correlations between these parameters were assessed. Syndromic obese cases and cases with missing test results were not included in the study.

Body weight measurements were conducted using a “Barimed ${ }^{\circledR}$ Electronic Body Scale SC-105" with 0.1 kg accuracy, after a 10-hour fasting period, barefoot, and with daily clothes on. Heights were measured with "Ayrton ${ }^{\circledR}$ Stadiometer Model S100" with $0.1 \mathrm{~cm}$ accuracy, $\geq$ barefoot. BMI was calculated using the $\mathrm{kg} / \mathrm{m}^{2}$ formula. According to age and gender, a subject with a BMI value $\geq 95^{\text {th }}$ percentile was considered as obese. The BMI percentile and BMI standard deviation (SD) values were calculated using the reference values developed by Neyzi et al (8).

Tanner staging was used for evaluation of puberty development. A testicle volume of $\geq 4 \mathrm{~mL}$ in males and presence of breast development Tanner stage $\geq 2$ in females were accepted as signs indicating initiation of puberty $(9,10)$.

Blood samples taken from patients after 8-10 hours of fasting were evaluated with standard methods using a Roche Modular-P 800 device. Fasting blood glucose, TC, TG, HDL-C, alanine aminotransferase (ALT) and aspartate aminotransferase (AST) levels were analyzed. LDL-C levels were calculated with available lipid data using the Friedewald formula (11). Serum TC levels over $200 \mathrm{mg} / \mathrm{dL}, \mathrm{TG}$ levels over $150 \mathrm{mg} / \mathrm{dL}, \mathrm{LDL}-\mathrm{C}$ levels over $130 \mathrm{mg} / \mathrm{dL}$, or HDL-C levels under $40 \mathrm{mg} / \mathrm{dL}$ were accepted as dyslipidemia $(12,13)$. According to reference values of ALT and AST kits used in our hospital laboratories, ALT and AST normal values were set as below $41 \mathrm{U} / \mathrm{L}$ and 37 $U / L$, respectively.

Fasting insulin, thyroid-stimulating hormone (TSH), and free thyroxine $\left(\mathrm{fT}_{4}\right)$ levels were studied with 2-chamber 2-step enzymatic immunoassay methods using a Beckman Coulter Dxl 800 device. According to reference values of Beckmann Coulter TSH and $\mathrm{fT}_{4}$ kits used in our hospital laboratories, $\mathrm{TSH}$ low and high limit values were set as $0.34-5.6 \mathrm{mlU} / \mathrm{mL}$ and $\mathrm{fT}_{4}$ low and high limit values were set as 0.6-1.2 ng/dL.

IR was evaluated with homeostasis model of assessment for insulin resistance (HOMA-IR) index using the following equation: fasting insulin concentration $(\mu \mathrm{U} / \mathrm{mL}) \times$ fasting glucose concentration (mmol/L)/22.5 (14). For IR, HOMA-IR cut-off values were accepted as 2.5 in prepubertal and 4.0 in pubertal patients (15).
Upper abdominal ultrasonographic examination was used for diagnosis of hepatosteatosis in the radiology department of our hospital using a Toshiba Xarioi Style ultrasound device. Liver ultrasound findings were staged as follows: normal liver appearance (no hepatosteatosis), mild (stage 1), moderate (stage 2) and severe hepatosteatosis (stage 3) (16).

The subjects were classified into 3 groups according to evaluation of clinical and laboratory results of dyslipidemia and hepatosteatosis.

Group 1: Cases with both dyslipidemia and grade 2-3 hepatosteatosis

Group 2: Cases with dyslipidemia or hepatosteatosis

Group 3: Cases without dyslipidemia and hepatosteatosis

The study proposal was approved by the Ethics Committee of Ankara Children's Hematology and Oncology Training and Research Hospital (Approval number: 2014-043).

\section{Statistical Analysis}

Statistical analysis was performed using the Statistical Package for the Social Sciences version 17.0 (SPSS, Inc. Chicago IL, USA, Microsoft). Values were given as mean \pm standard deviation (minimum-maximum). Student's t-test was used to compare means of numeric variables, and chi-square test was used to compare non-numeric variables. One-way ANOVA test was used to compare numeric variables in groups in three (Post hoc: Bonferroni). Significance was accepted as $p<0.05$.

\section{Results}

The mean age of the 823 (459 female, 364 male) obese patients in the study was $10.8 \pm 3.1$ years; $60.8 \%$ of them were pubertal. Demographic features of the patients and laboratory data are shown in Table 1.

In our study group, 353 (42.9\%) patients met the dyslipidemia criteria: $21.7 \%$ of the patients had hypertriglyceridemia, $19.7 \%$ had low levels of HDL-C, $18.6 \%$ had hypercholesterolemia, and $13.7 \%$ had high levels of LDL-C. There was no statistical difference in the prevalence of dyslipidemia according to sex. Older age and/or high BMI were related with increased prevalence of dyslipidemia ( $p=0.047$ and $p=0.045$, respectively) (Table 2). In pubertal obese patients, TG levels were higher and incidence of hypertriglyceridemia was higher than in the others $(p<0.001$ and $p=0.006$, respectively).

Among patients with dyslipidemia, 223 (63\%) had hepatosteatosis, 102 (28.9\%) had IR, 28 (7\%) had high ALT levels, 23 (6.5\%) had high AST levels, and 14 (3\%) had hypothyroidism. Dyslipidemic patients had a higher proportion of hepatosteatosis, IR and higher levels of ALT and TSH when compared to the non-dyslipidemic group $(\mathrm{p}<0.05)$. $\mathrm{fT}_{4}$ and AST levels did not show any significant difference between these groups (Table 2). In patients with stage 1 hepatosteatosis, thyroid function tests were not affected, but ALT levels were higher as compared to patients without hepatosteatosis. On the other hand, ALT, AST, and TSH values were higher and $\mathrm{fT}_{4}$ was lower in patients with stage 2-3 hepatosteatosis (Table 3). 
Elmaoğulları S et al

Dyslipidemia in Obese Children

Table 1. Demographic features of the patients and laboratory findings by gender and pubertal state

\begin{tabular}{|c|c|c|c|c|c|c|c|}
\hline & Total & Female & Male & $\mathbf{p}^{*}$ & Prepubertal & Pubertal & $\mathrm{p}^{* *}$ \\
\hline$n(\%)$ & $823(100.0)$ & $459(55.8)$ & $364(44.2)$ & & $323(39.2)$ & $500(60.8)$ & \\
\hline Age (years) & $10.8 \pm 3.1$ & $10.9 \pm 3.2$ & $10.6 \pm 2.9$ & NS & $7.8 \pm 1.9$ & $12.6 \pm 2.1$ & $<0.001$ \\
\hline $\mathrm{BMI}\left(\mathrm{kg} / \mathrm{m}^{2}\right)$ & $28.3 \pm 4.8$ & $28.1 \pm 4.9$ & $28.4 \pm 4.5$ & NS & $25.0 \pm 3.1$ & $30.3 \pm 4.8$ & $<0.001$ \\
\hline BMI SDS & $2.5 \pm 0.6$ & $2.6 \pm 0.7$ & $2.4 \pm 0.5$ & $<0.001$ & $2.4 \pm 0.61$ & $2.5 \pm 0.7$ & NS \\
\hline Fasting glucose (mg/dL) & $89.2 \pm 7.3$ & $88.4 \pm 7.6$ & $90.1 \pm 6.7$ & 0.001 & $88.1 \pm 6.4$ & $89.8 \pm 7.8$ & 0.001 \\
\hline Fasting insulin (IU/mL) & $12.4 \pm 9.1$ & $13.0 \pm 9.0$ & $11.6 \pm 9.2$ & NS & $9.0 \pm 5.8$ & $14.6 \pm 10.2$ & $<0.001$ \\
\hline HOMA-IR & $2.8 \pm 2.6$ & $2.9 \pm 2.3$ & $2.6 \pm 2.4$ & NS & $2.0 \pm 1.4$ & $3.3 \pm 2.7$ & $<0.001$ \\
\hline $\operatorname{IR} n(\%)$ & $187(22.7)$ & $97(21.1)$ & $90(24.7)$ & NS & $72(22.3)$ & $115(23)$ & NS \\
\hline $\mathrm{TC}(\mathrm{mg} / \mathrm{dL})$ & $172.6 \pm 32.7$ & $172.1 \pm 0.3$ & $173.3 \pm 32.9$ & NS & $171.3 \pm 31.6$ & $173.6 \pm 33.5$ & NS \\
\hline $\mathrm{TG}(\mathrm{mg} / \mathrm{dL})$ & $119.0 \pm 62.2$ & $115.4 \pm 55.2$ & $123.5 \pm 70.0$ & NS & $109.3 \pm 53.5$ & $125.3 \pm 66.6$ & $<0.001$ \\
\hline LDL-C (mg/dL) & $100.0 \pm 28.3$ & $100 \pm 28.3$ & $100.0 \pm 28.2$ & NS & $100.1 \pm 26.8$ & $100.0 \pm 29.3$ & NS \\
\hline $\mathrm{HDL}-\mathrm{C}(\mathrm{mg} / \mathrm{dL})$ & $48.5 \pm 11.3$ & $48.7 \pm 11.0$ & $48.3 \pm 11.6$ & NS & $49.5 \pm 11.6$ & $48.0 \pm 11.1$ & NS \\
\hline Dyslipidemia n (\%) & $353(42.9)$ & $186(40.5)$ & $167(45.9)$ & NS & $132(40.9)$ & $221(44.2)$ & NS \\
\hline Hypercholesterolemia & $153(18.6)$ & 75 (16.3) & 78 (21.4) & NS & $54(16.7)$ & $99(19.8)$ & NS \\
\hline Hypertriglyceridemia & $179(21.7)$ & $91(19.8)$ & $88(24.2)$ & NS & $54(16.7)$ & $125(25.0)$ & 0.006 \\
\hline High LDL-C levels & $110(13.4)$ & $58(12.6)$ & $52(14.3)$ & NS & $42(13.0)$ & $68(13.6)$ & NS \\
\hline Low HDL-C levels & $162(19.7)$ & $88(19.2)$ & $74(20.3)$ & NS & $61(18.9)$ & $101(20.2)$ & NS \\
\hline Hepatosteatosis n (\%) & $464(56.4)$ & $244(53.1)$ & $220(60.4)$ & 0.018 & $137(42.4)$ & $337(65.4)$ & $<0.0001$ \\
\hline Grade 1 & $320(38.9)$ & $180(39.2)$ & $140(38.4)$ & NS & $107(33.1)$ & $213(42.6)$ & $<0.0001$ \\
\hline Grade 2-3 & 144 (17.5) & $64(14.0)$ & $80(22.0)$ & 0.002 & $30(9.3)$ & $124(22.8)$ & $<0.0001$ \\
\hline
\end{tabular}

\section{Discussion}

In this study, dyslipidemia prevalence was found as $43 \%$ in 823 obese children and adolescents. In our study group, dyslipidemia was observed most frequently as hypertriglyceridemia. Frequency of dyslipidemia was related with older age and higher BMI. There are several studies reporting different dyslipidemia rates $(17,18,19,20)$. Prevalence of dyslipidemia changed between $10.7 \%$ and $69.9 \%$ among obese children in different populations. In a previous report on Turkish children, Cizmecioglu et al (21) have reported a dyslipidemia prevalence of $42.9 \%$ in 112 school-aged obese children, a finding very similar to our results. Korsten-Reck et al (17) have reported a dyslipidemia incidence of $45.8 \%$ in 546 German children. Hypertriglyceridemia was found to be more common than high LDL-C and low HDL-C levels in both of the above studies. Frequency of dyslipidemia was reported as $69.9 \%$ in 2064 obese Iranian children; frequency of hypertriglyceridemia was reported in $49.9 \%$ of the children included in this study. A low HDL-C was reported in $60 \%$ of Mexican obese adolescents with metabolic syndrome $(18,19)$. In 538 Chinese obese male children, hypertriglyceridemia prevalence was found to be $10.7 \%$ and hypercholesterolemia rate was $14.2 \%$ (20). Variations in reported prevalence rates can be due to dietary habits in different cultures, or to ethnicity, different inclusion criteria, BMI variation (also including overweight cases in some studies), and differences in dyslipidemia definition.

Dyslipidemia is more common in obese patients than in non-obese ones $(22,23)$. In obesity, high amounts of free fatty 
Table 2. Clinical and laboratory differences between dyslipidemia $(+)$ and (-) cases

\begin{tabular}{|c|c|c|c|}
\hline & Dyslipidemia $(+)(n=353)$ & Dyslipidemia (-) $(n=470)$ & p \\
\hline Age (years) & $11.0 \pm 3.0$ & $10.6 \pm 3.2$ & 0.047 \\
\hline Gender (Female/Male) & $(186 / 167)$ & $(273 / 197)$ & NS \\
\hline Puberty (prepubertal/pubertal) & $(132 / 221)$ & $(191 / 279)$ & NS \\
\hline $\mathrm{BMI}\left(\mathrm{kg} / \mathrm{m}^{2}\right)$ & $28.9 \pm 4.9$ & $27.8 \pm 4.5$ & $<0.0001$ \\
\hline BMI SDS & $2.5 \pm 0.7$ & $2.4 \pm 0.6$ & 0.045 \\
\hline Fasting insulin (IU/mL) & $14.1 \pm 11.8$ & $11.1 \pm 6.2$ & $<0.001$ \\
\hline HOMA-IR & $3.22 \pm 3.2$ & $2.47 \pm 1.4$ & $<0.001$ \\
\hline IR n (\%) & $102(28)$ & $85(18)$ & $<0.001$ \\
\hline $\operatorname{ALT}(\mathrm{U} / \mathrm{L})$ & $24.7 \pm 15$ & $21.7 \pm 14$ & 0.004 \\
\hline AST (U/L) & $24.7 \pm 7$ & $24.5 \pm 8$ & NS \\
\hline Hepatosteatosis Grade 2-3 n (\%) & $78(22)$ & $66(14)$ & 0.003 \\
\hline TSH (mIU/mL) & $2.96 \pm 2.4$ & $2.54 \pm 1.2$ & 0.001 \\
\hline $\mathrm{fT}_{4}(\mathrm{ng} / \mathrm{dL})$ & $0.88 \pm 0.1$ & $0.89 \pm 0.1$ & NS \\
\hline Hypothyroidism n (\%) & $14(3.9)$ & $12(2.5)$ & NS \\
\hline
\end{tabular}

Table 3. Comparison between laboratory findings in dyslipidemia and/or hepatosteatosis groups

\begin{tabular}{|c|c|c|c|}
\hline & $\begin{array}{l}\text { Group } 1 \\
\text { Both hepatosteatosis } \\
\text { and dyslipidemia }\end{array}$ & $\begin{array}{l}\text { Group } 2 \\
\text { Dyslipidemia or } \\
\text { hepatosteatosis }\end{array}$ & $\begin{array}{l}\text { Group } 3 \\
\text { No hepatosteatosis or } \\
\text { dyslipidemia }\end{array}$ \\
\hline$n(\%)$ & $78(9.5)$ & $335(40.7)$ & $410(49.8)$ \\
\hline Fasting glucose $(\mathrm{mg} / \mathrm{dL})$ & $90.9 \pm 11.6$ & $89.3 \pm 6.9$ & $88.7 \pm 6.4$ \\
\hline Fasting insulin (IU/mL) & $18.8 \pm 15.1 \alpha \beta$ & $13.2 \pm 9.9^{x}$ & $10.4 \pm 5.7$ \\
\hline HOMA-IR & $4.4 \pm 4.1 \alpha \beta$ & $2.9 \pm 2.7^{\chi}$ & $2.3 \pm 1.4$ \\
\hline $\mathrm{TSH}(\mathrm{mlU} / \mathrm{mL})$ & $3.3 \pm 3.9 \beta$ & $2.9 \pm 1.8^{\chi}$ & $2.5 \pm 1.2$ \\
\hline $\mathrm{fT}_{4}(\mathrm{ng} / \mathrm{dL})$ & $0.84 \pm 0.14 \alpha \beta$ & $0.89 \pm 0.13$ & $0.89 \pm 0.13$ \\
\hline ALT (U/L) & $35.6 \pm 22.6 \alpha \beta$ & $24.7 \pm 17.1^{\chi}$ & $19.3 \pm 9.0$ \\
\hline AST (U/L) & $27.5 \pm 11.3 \beta$ & $24.6 \pm 8.5^{\chi}$ & $24.0 \pm 6.5$ \\
\hline
\end{tabular}

acid (FFA) are released due to lipolysis. These FFAs lead to hypertriglyceridemia by inhibiting lipoprotein lipase in adipose and muscle tissues, in addition to increased production of verylow-density lipoprotein (VLDL) and TG in the liver. Degradation of TG-rich LDL-C and HDL-C caused by hypertriglyceridemia with hepatic lipase leads to increasing low LDL-C levels and decreasing HDL-C levels. Increased low LDL-C and decreased HDL-C levels are major factors for development of atherosclerosis and CVD $(24,25)$.

The relationship between dyslipidemia and higher BMI values in our study is compatible with results reported in previous studies (26). Cut-off BMI-standard deviation score
(SDS) for dyslipidemia was determined as 1.22 by Gong et al (20). However, since adipose and muscle tissue cannot be differentiated, BMI is thought to be an invaluable indicator for dyslipidemia or CVD $(19,27)$. In one study evaluating CVD risk factors, BMI-SDS was shown as an effective indicator for hypertension and waist circumference SDS was shown to be an effective indicator for dyslipidemia (28).

A high amount of adipose tissue influences insulin release and functions through direct lipotoxic effect and leads to secretion of immune cytokines (29). Muscle cells which are an important reservoir for glucose become irresponsive to insulin in the presence of extreme amounts of FFA, TG and 
other lipid metabolites due to obesity and dyslipidemia $(30,31)$. Compensatory hyperinsulinemia leads to increased VLDL, TG and FFA production and decreased HDL-C levels in the liver. Meanwhile, lipogenesis is increased in peripheral tissue due to IR (32). Due to this vicious cycle between dyslipidemia and $I R$, in our study, higher HOMA-IR values were detected in dyslipidemic patients, and the number of cases with IR was found to be significantly higher in this group. This relationship was also highlighted in some previous studies $(33,34)$.

The most common cause of chronic liver disease in children is non-alcoholic fatty liver disease (NAFLD). In the past 20 years, the incidence of NAFLD has increased, in parallel with the increase in obesity. In obese individuals, because of dyslipidemia and IR, lipid intake and production in the liver overcomes lipid clearance, leading to development of hepatosteatosis. Steatosis is the first hit in the 'two hit' theory of NAFLD pathogenesis. Oxidant, inflammatory or toxic damage constitute the second hit and lead to hepatosteatosis and cirrhosis (35). Differentiation of steatosis, steatohepatitis, and cirrhosis can be distinctly done with pathological sampling. Intensity of hepatosteatosis can be evaluated with ultrasound. In our study, hepatosteatosis was detected in $56 \%$ of the patients and in $63 \%$ of dyslipidemic patients. Grade $2-3$ hepatic steatosis rates were found as $22 \%$ in dyslipidemic cases and $14 \%$ in others. In cases with dyslipidemia, hepatosteatosis rate was significantly higher than in cases without dyslipidemia. According to results from various studies, NAFLD incidence is between $12 \%$ and $68 \%(20,36,37)$. These different results are thought to be related to subjectivity of diagnosis and staging of hepatosteatosis with USG and the wide range of BMI values and number of patients in these different studies.

Liver function tests are usually normal in children with hepatosteatosis. High ALT levels usually demonstrate development of steatohepatitis (38). ALT levels were found to be higher in the presence of hepatosteatosis or dyslipidemia compared to other patients in our group. In stage 2-3 hepatosteatosis, ALT levels were even higher, and in addition to ALT, AST levels were also increased.

In the studies evaluating changes in TSH level and thyroid function tests in obese children, TSH and free triiodothyronine levels were reported to be higher and $\mathrm{fT}_{4}$ levels lower compared to healthy controls $(39,40,41)$. These changes occur usually within normal limits and are proposed to be a part of the adaptation process to obesity (41). Increase in leptin levels and cytokines secreted from adipose tissue causes increase in deiodinase activity and decrease in iodine uptake in thyroid tissue. Changes in thyroid function are reversible and thyroid function tests become normal after losing weight (42). Thyroid hormone is an important modulator in the lipid metabolism. It shows a hypolipidemic effect by regulating lipid synthesis and oxidation (43). Hypercholesterolemia and hypertriglyceridemia are known to develop in hypothyroidism $(44,45)$. In our study, TSH levels were found to be higher in the presence of dyslipidemia as compared to the levels in obese cases without dyslipidemia. In a study by Santos-Palasios et al (46), thyroid functions and lipid profiles of 20783 adult patients were evaluated and even within the normal reference range, lipid profile was found to be disrupted with increasing TSH. In stage 2-3 hepatosteatosis, TSH levels were increased and $\mathrm{fT}_{4}$ were decreased in reference ranges in our study. This change was even more significant when there is dyslipidemia concurrently with hepatosteatosis. In two recent studies, increased TSH levels were found to be correlated with hepatosteatosis and high ALT levels $(47,48)$. It is stated that this situation could be related to sick euthyroid syndrome (49). Dullaart et al's study (48) has also shown that low thyroid functions within normal limits correlate to higher ALT levels in the presence of IR and metabolic syndrome.

In conclusion, studies have shown that dyslipidemia prevalence is high in obese children and that it increases with age. IR and hepatosteatosis are more frequent in dyslipidemic patients. If there is hepatosteatosis coexisting with dyslipidemia, changes in thyroid functions are more apparent. In the evaluation of obese children and adolescents with dyslipidemia, it should be remembered that clinical and metabolic problems related to obesity might be severe and should be monitored closely.

\section{References}

1. Han JC, Lawlor DA, Kimm SY. Childhood obesity. Lancet 2010;375:1737-1748. Epub 2010 May 5

2. de Onis $M$, Blössner M, Borghi E. Global prevalence and trends of overweight and obesity among preschool children. Am J Clin Nutr 2010;92:1257-1264. Epub 2010 Sep 22

3. Discigil G, Tekin N, Soylemez A. Obesity in Turkish children and adolescents: prevalence and non-nutritional correlates in an urban sample. Child Care Health Dev 2009;35:153-158.

4. Roger VL, Go AS, Lloyd-Jones DM, Benjamin EJ, Berry JD, Borden WB, Bravata DM, Dai S, Ford ES, Fox CS, Fullerton HJ, Gillespie C,Hailpern SM, Heit JA, Howard VJ, Kissela BM, Kittner SJ, Lackland DT, Lichtman JH, Lisabeth LD, Makuc DM, Marcus GM, Marelli A,Matchar DB, Moy CS, Mozaffarian D, Mussolino ME, Nichol G, Paynter NP, Soliman EZ, Sorlie PD, Sotoodehnia N, Turan TN, Virani SS,Wong ND, Woo D, Turner MB; American Heart Association Statistics Committee and Stroke Statistics Subcommittee. Heart disease and stroke statistics-2012 update: a report from the American Heart Association. Circulation 20123;125:2-220. Epub 2011 Dec 15

5. Raitakari OT, Juonala M, Kähönen M, Taittonen L, Laitinen T, Mäki-Torkko N, Järvisalo MJ, Uhari M, Jokinen E, Rönnemaa T, Akerblom HK, Viikari JS. Cardiovascular risk factors in childhood and carotid artery intima-media thickness in adulthood: the Cardiovascular Risk in Young Finns Study. JAMA 2003;290:2277-2283.

6. Berenson GS, Srinivasan SR, Bao W, Newman WP 3rd, Tracy RE, Wattigney WA. Association between multiple cardiovascular risk factors and atherosclerosis in children and young adults. The Bogalusa Heart Study. N Engl J Med 1998;338:1650-1656. 
7. Steinberger J. Diagnosis of the metabolic syndrome in children. Curr Opin Lipidol 2003;14:555-559.

8. Neyzi O, Günöz H, Furman A, Bundak R, Gökçay G, Darendeliler F. Bas F. Türk çocuklarında vücut ağırlığı, boy uzunluğu, başçevresi ve vücut kitle indeksi referans değerleri. Çocuk Sağlığı ve Hastalıkları Dergisi 2008;51:1-14.

9. Rosenfield RL, Cooke DW, Radovick S. Puberty and Its Disorders in the Female. In: Sperling MA (ed). Pediatric Endocrinology, 2013;569-663.

10. Palmert MR, Dunkel L, Witchel SF. Puberty and Its Disorders in the Male. In: Sperling MA (ed). Pediatric Endocrinology, 2013;697-733.

11. Warnick GR, Knopp RH, Fitzpatrick V, Branson L. Estimating low-density lipoprotein cholesterol by the Friedewald equation is adequate for classifying patients on the basis of nationally recommended cut points. Clin Chem 1990;36:1519.

12. Daniels SR, Greer FR; Committee on Nutrition. Lipid screening and cardiovascular health in childhood. Pediatrics 2008;122:198-208.

13. Tamir I, Heiss G, Glueck CJ, Christensen B, Kwiterovich P, Rifkind BM. Lipid and lipoprotein distributions in white children ages 6-19 yr. The lipid research clinics program prevalence study. J Chronic Dis 1981;34:27-39.

14. Matthews DR, Hosker JP, Rudenski AS, Naylor BA, Treacher DF, Turner RC. Homeostasis model assessment: insulin resistance and beta-cell function from fasting plasma glucose and insulin concentrations in man. Diabetologia 1985;28:412-419.

15. Valerio $G$, Licenziati $M R$, lannuzzi $A$, Franzese $A$, Siani $P$, Riccardi G, Ruba P. Insulin resistance and impaired glucose tolerance in obese children and adolescents from Southern Italy. Nutr Metab Cardiovasc Dis 2006;16:279-284.

16. Mert A, Kılıç I. Karaciğer Ultrasonografisi, Yağlı Karaciğer, in Ultrasonografiye Giriş Cilt 1-1997.

17. Korsten-Reck U, Kromeyer-Hauschild K, Korsten K, Baumstark MW, Dickhuth $\mathrm{HH}$, Berg A. Frequency of secondary dyslipidemia in obese children. Vasc Health Risk Manag 2008:4:1089-1094.

18. Hashemipour M, Soghrati M, MalekAhmadi M, Soghrati M. Anthropometric indices associated with dyslipidemia in obese children and adolescents: a retrospective study in isfahan. ARYA Atheroscler 2011;7:31-39.

19. Evia-Viscarra ML, Rodea-Montero ER, Apolinar-Jiménez E, Quintana-Vargas S. Metabolic syndrome and its components among obese (BMI >=95th) Mexican adolescents. Endocr Connect 2013;2:208-215.

20. Gong CD, Wu QL, Chen Z, Zhang D, Zhao ZY, Peng YM. Glycolipid metabolic status of overweight/obese adolescents aged 9- to 15-year-old and the BMI-SDS/BMI cut-off value of predicting dyslipidemiain boys, Shanghai, China: a crosssectional study. Lipids Health Dis 2013;12:129.

21. Cizmecioglu FM, Hatun S, Kalaça S. Metabolic syndrome in obese Turkish children and adolescents: comparison of two diagnostic models. Turk J Pediatr 2008;50:359-365.

22. Freedman DS, Dietz WH, Srinivasan SR, Berenson GS. The relation of overweight to cardiovascular risk factors among children and adolescents: the Bogalusa Heart Study. Pediatrics 1999;103:1175-1182.

23. Yang S, Hwang JS, Park HK, Lee HS, Kim HS, Kim EY, Lim JS. Serum lipid concentrations, prevalence of dyslipidemia, and percentage eligible for pharmacological treatment of Korean children and adolescents; data from the Korea National Health and Nutrition Examination Survey IV (2007-2009). PLoS One 2012;7:49253.
24. Klop B, Elte JW, Cabezas MC. Dyslipidemia in obesity: mechanisms and potential targets. Nutrients 2013;5:12181240.

25. National Cholesterol Education Program (NCEP) Expert Panel on Detection, Evaluation, and Treatment of High Blood Cholesterol in Adults (Adult Treatment Panel III). Third report of the national cholesterol education program (NCEP) expert panel on detection, evaluation, and treatment of high blood cholesterol in adults (Adult treatment panel III) final report. Circulation 2002;106:3143-3421.

26. Haas GM, Bertsch T, Schwandt P. Prehypertension and cardiovascular risk factors in children and adolescents participating in the community-based prevention education program family heart study. Int J Prev Med 2014;5(Suppl 1):50-56

27. Weisell RC. Body mass index as an indicator of obesity. Asia Pacific J Clin Nutr 2002;11(Suppl 7):681-684.

28. Gröber-Grätz $D$, Widhalm K, de Zwaan $M$, Reinehr T, Blüher S, Schwab KO, Wiegand S, Holl RW. Body mass index or waist circumference: which is the better predictor for hypertension and dyslipidemia in overweight/obese children and adolescents? Association of cardiovascular risk related to body mass index or waist circumference. Horm Res Paediatr 2013;80:170-178.

29. Holland WL, Bikman BT, Wang LP, Yuguang G, Sargent KM, Bulchand S, Knotts TA, Shui G, Clegg DJ, Wenk MR, Pagliassotti MJ, Scherer PE, Summers SA. Lipidinduced insulin resistance mediated by the proinflammatory receptor TLR4 requires saturated fatty acid-induced ceramide biosynthesis in mice. J Clin Invest 2011;121:1858-1870.

30. Holland WL, Knotts TA, Chavez JA, Wang LP, Hoehn KL, Summers SA. Lipid mediators of insulin resistance. Nutr Rev 2007;65:39-46.

31. Savage DB, Petersen KF, Shulman GI. Disordered lipid metabolism and the pathogenesis of insulin resistance. Physiol Rev 2007;87:507-520.

32. Li N, Fu J, Koonen DP, Kuivenhoven JA, Snieder H, Hofker $\mathrm{MH}$. Are hypertriglyceridemia and low HDL causal factors in the development of insulin resistance? Atherosclerosis 2014;233:130-138. Epub 2014 Jan 7

33. Yoshitomi Y, Ishii T, Kaneki M, Tsujibayashi T, Sakurai $S$, Nagakura C, Miyauchi A. Relationship between insulin resistance and effect of atorvastatin in non-diabetic subjects. J Atheroscler Thromb 2005;12:9-13.

34. Raitakari OT, Porkka KV, Rönnemaa T, Knip M, Uhari $M$, Akerblom HK, Viikari JS. The role of insulin in clustering of serum lipids and blood pressure in children and adolescents. The cardiovascular risk in young finns study. Diabetologia 1995;38:1042-1050.

35. Bozic MA, Subbarao G, Molleston JP. Pediatric nonalcoholic fatty liver disease. Nutr Clin Pract 2013;28:448-458.

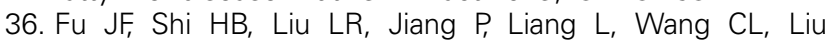
$X Y$. Non-alcoholic fatty liver disease: an early mediator predicting metabolic syndrome in obese children? World J Gastroenterol 2011;17:735-742.

37. Arslan N, Büyükgebiz B, Oztürk $Y$, Cakmakçi H. Fatty liver in obese children: prevalence and correlation with anthropometric measurements and hyperlipidemia. Turk J Pediatr 2005;47:23-27.

38. Chan DF, Li AM, Chu WC, Chan MH, Wong EM, Liu EK, Chan IH, Yin J, Lam CW, Fok TF, Nelson EA. Hepatic steatosis in obese Chinese children. Int J Obes Relat Metab Disord 2004;28:1257-1263. 
Elmaoğulları S et al.

Dyslipidemia in Obese Children

39. Marras V, Casini MR, Pilia S, Carta D, Civolani P, Porcu M, Uccheddu AP, Loche S. Thyroid function in obese children and adolescents. Horm Res Paediatr 2010;73:193-197. Epub 2010 Mar 3

40. Biondi B. Thyroid and obesity: an intriguing relationship. J Clin Endocrinol Metab 2010;95:3614-3617.

41. Baş VN, Aycan Z, Ağladıoğlu SY, Kendirci HN. Prevalence of hyperthyrotropinemia in obese children before and after weight loss. Eat Weight Disord 2013;18:87-90. Epub 2013 Apr 3

42. Longhi S, Radetti G. Thyroid function and obesity. J Clin Res Pediatr Endocrinol 2013;5(Suppl 1):40-44. Epub 2012 Nov 1

43. Cordeiro A, Souza LL, Einicker-Lamas M, Pazos-Moura CC. Non-classic thyroid hormone signalling involved in hepatic lipid metabolism. J Endocrinol 2013;216:47-57.

44. Erem C, Değer O, Bostan M, Orem A, Sönmez M, Ulusoy $\mathrm{S}$, Telatar M. Plasma lipoprotein (a) concentrations in hypothyroid, euthyroid and hyperthyroid subjects. Acta Cardiol 1999;54:77-81.
45. Pucci E, Chiovato L, Pinchera A. Thyroid and lipid metabolism. Int J Obes Relat Metab Disord 2000;24(Supll2):109-112.

46. Santos-Palacios S, Brugos-Larumbe A, Guillén-Grima F, Galofré JC. A cross-sectional study of the association between circulating TSH level and lipid profile in a large Spanish population.Clin Endocrinol (Oxf) 2013;79:874-881. Epub 2013 Apr 23

47. Torun E, Özgen IT, Gökçe S, Aydın S, Cesur Y. Thyroid hormone levels in obese children and adolescents with nonalcoholic fatty liver disease. J Clin Res Pediatr Endocrinol 2014;6:34-39.

48. Dullaart RP, van den Berg EH, van der Klauw MM, Blokzijl $\mathrm{H}$. Low normal thyroid function attenuates serum alanine aminotransferase elevations in the context of metabolic syndrome and insulin resistance in white people. Clin Biochem 2014;47:1028-1032. Epub 2014 Apr 21

49. Eshraghian $A$, Dabbaghmanesh $M H$, Eshraghian $H$, Fattahi MR, Omrani GR. Nonalcoholic fatty liver disease in a cluster of Iranian population: thyroid status and metabolic risk factors. Arch Iran Med 2013;16:584-589. 